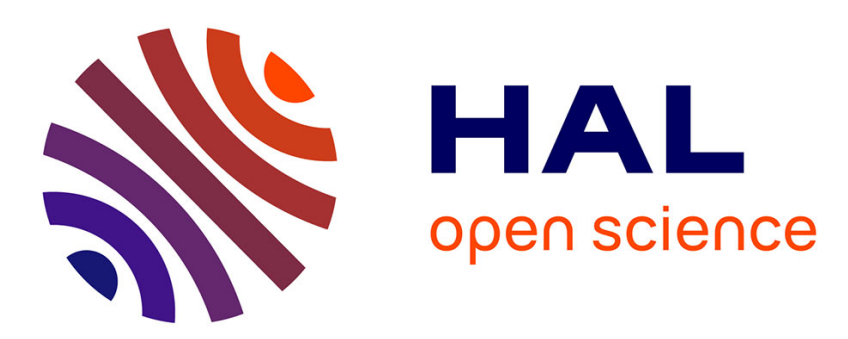

\title{
Cation selectivity in sodium-calcium, sodium-magnesium, and calcium-magnesium exchange on wyoming bentonite at $298 \mathrm{~K} 1$
}

Garrison Sposito, Kenneth M Hotzclaw, Claire Jouany, Laurent Charlet

\section{- To cite this version:}

Garrison Sposito, Kenneth M Hotzclaw, Claire Jouany, Laurent Charlet. Cation selectivity in sodium-calcium, sodium-magnesium, and calcium-magnesium exchange on wyoming bentonite at 298 K1. Soil Science Society of America Journal, 1983, 47 (5), pp.917-921. 10.2136/sssaj1983.03615995004700050015x . hal-02728744

\section{HAL Id: hal-02728744 \\ https://hal.inrae.fr/hal-02728744}

Submitted on 2 Jun 2020

HAL is a multi-disciplinary open access archive for the deposit and dissemination of scientific research documents, whether they are published or not. The documents may come from teaching and research institutions in France or abroad, or from public or private research centers.
L'archive ouverte pluridisciplinaire HAL, est destinée au dépôt et à la diffusion de documents scientifiques de niveau recherche, publiés ou non, émanant des établissements d'enseignement et de recherche français ou étrangers, des laboratoires publics ou privés. 


\title{
Cation Selectivity in Sodium-Calcium, Sodium-Magnesium, and Calcium-Magnesium Exchange on Wyoming Bentonite at $298 \mathrm{~K}^{1}$
}

\author{
Garrison Sposito, Kenneth M. Holtzclaw, Claire Jouany, and Laurent Charlet ${ }^{2}$
}

\begin{abstract}
Exchange isotherms were prepared for $\mathrm{Na}^{+}$in $\mathrm{Na}^{+} \rightarrow \mathrm{Ca}^{2+}$ and $\mathrm{Na}^{+} \rightarrow \mathrm{Mg}^{2+}$ exchange reactions, and for $\mathrm{Mg}^{2+}$ in $\mathrm{Ca}^{2+} \rightarrow \mathrm{Mg}^{2+}$ exchange reactions, at $298 \mathrm{~K}$ on Wyoming bentonite suspended in a $0.05 M$ perchlorate background. These isotherms were essentially congruent with the appropriate thermodynamic nonpreference exchange isotherms. It was concluded from this fact that there is essentially no difference in the affinity of montmorillonite clay for $\mathrm{Ca}^{2+}$ vs. $\mathrm{Mg}^{2+}$. However, exchange isotherms prepared for $\mathrm{Na}^{+}$in $\mathrm{Na}(\mathrm{I}) \rightarrow \mathrm{Ca}(\mathrm{II})$ and $\mathrm{Na}(\mathrm{I}) \rightarrow \mathrm{Mg}(\mathrm{II})$ exchange, as well as published ones for $\mathrm{Mg}$ (II) in $\mathrm{Ca}$ (II) $\rightarrow \mathrm{Mg}$ (II) exchange on montmorillonite suspended in a $0.05 M$ chloride background consistently indicate a slight preference on the clay for $\mathrm{Ca}(\mathrm{II})$ over $\mathrm{Mg}(\mathrm{II})$. This preference for $\mathrm{Ca}(\mathrm{II})$ is concluded to be the result of the formation of $\mathrm{CaCl}^{+}$ complexes, which are more stable thermodynamically and have a greater affinity for the clay than $\mathrm{MgCl}^{+}$complexes.
\end{abstract}

Additional Index Words: cation exchange, chloride complexes, saline soils, thermodynamics of cation exchange.

Sposito, G., K.M. Holtzclaw, C. Jouany, and L. Charlet. 1983. Cation selectivity in sodium-calcium, sodium-magnesium, and calcium-magnesium exchange on Wyoming bentonite at $298 \mathrm{~K}$. Soil Sci. Soc. Am. J. 47:917-921.

$\mathrm{O}$ NE OF THE CENTRAL PROBLEMS in the chemistry of arid-zone soils is the quantitative characterization of an exchange complex bearing sodium, calcium, and magnesium ions. Rahman and Rowell (1979) and Bresler et al. (1982, part 1) have reviewed this problem recently and have brought into clear focus the two objectives of understanding the patterns of $\mathrm{Na}-\mathrm{Ca}-\mathrm{Mg}$ exchange reactions and of predicting the effect of exchanger composition on soil physical properties. The consensus of the literature is that exchangeable sodium percentage (ESP), electrolyte concentration, and soil mineralogy are the three master chemical variables on which the water-conducting properties of arid-zone soils depend. What remains is to develop a unified, quantitative description of the interrelations among these variables that is of predictive value.

Much of the research on $\mathrm{Na}-\mathrm{Ca}-\mathrm{Mg}$ exchange reactions has involved montmorillonite clay or montmorillonitic soils. In respect to exchange selectivity, the trends that have emerged from the results of published studies are: (i) for a given distribution of $\mathrm{Na}$ and bivalent cation in the aqueous solution phase, the resulting ESP on the clay is somewhat higher in $\mathrm{Na}-$ $\mathrm{Mg}$ exchange than in $\mathrm{Na}-\mathrm{Ca}$ exchange, and (ii) in $\mathrm{Ca}-$ $\mathrm{Mg}$ exchange, a small preference for $\mathrm{Ca}$ exists on the exchange complex (Schwertmann, 1962; Clark, 1966; Dolcater et al., 1968; Levy and Hillel, 1968; Hunsaker

\footnotetext{
${ }^{1}$ Contribution from the Dep. of Soil and Environmental Sciences, Univ. of California, Riverside, CA 92521 . Received 10 Nov. 1982. Approved 19 Apr. 1983.

${ }_{2}$ Professor of Soil Science, Research Associate IV, Visiting Postdoctoral Fellow, and Graduate Research Assistant, respectively.
}

and Pratt, 1971; Levy and Shainberg, 1972; Levy et al., 1972; van Bladel et al., 1973; Jensen and Babcock, 1973; Gheyi and van Bladel, 1975; Maes and Cremers, 1977; Rahman and Rowell, 1979; Rowell and Shainberg, 1979; van Bladel and Gheyi, 1980; Shainberg et al., 1980). The extent to which $\mathrm{Na}-\mathrm{Mg}$ exchange results in larger ESP values than $\mathrm{Na}-\mathrm{Ca}$ exchange is not pronounced, the differences being the order of 3 to 5 in ESP (Rahman and Rowell, 1979). The same is true of the selectivity of montmorillonite for calcium over magnesium. For example, van Bladel and Gheyi (1980) have reported a mean value of $0.8 \pm 0.1$ for the overall Vanselow selectivity coefficient,

$$
\mathrm{K}_{\mathrm{TV}}=\left(\mathrm{x}_{\mathrm{TMg}} \mathrm{Ca} \mathrm{a}_{\mathrm{T}}\right) /\left(\mathrm{x}_{\mathrm{TCa}} \mathrm{Mg}_{\mathrm{T}}\right)
$$

which describes the stoichiometric cation exchange reaction:

$$
\mathrm{CaX}_{2} \text { (s) }+\mathrm{MgCl}_{2} \text { (aq) }=\mathrm{MgX}_{2} \text { (s) }+\mathrm{CaCl}_{2} \text { (aq), }
$$

where $x_{T}$ is the mole fraction of all species of a metal in the exchanger phase, $\mathrm{M}_{\mathrm{T}}(\mathrm{M}=\mathrm{Ca}$ or $\mathrm{Mg})$ is the total molarity of all species of a metal in the aqueous solution phase, and $\mathrm{X}$ refers to $1 \mathrm{~mol}$ of negative charge on Camp Berteau montmorillonite clay. This mean value of $\mathrm{K}_{\mathrm{TV}}$ is only a little smaller than 1.0, the value that indicates no overall preference for calcium vs. magnesium on the clay.

A common feature in all of the experimental studies cited above [except one, that of Maes and Cremers (1977)] is the use of a chloride background ionic medium in which to carry out the exchange reactions. Sposito et al. (1983) have shown recently that, in chloride media, $\mathrm{Na}-\mathrm{Ca}$ and $\mathrm{Na}-\mathrm{Mg}$ exchange reactions on montmorillonite (Wyoming bentonite) actually are ternary cation exchange reactions, involving $\mathrm{Na}^{+}, \mathrm{M}^{2+}$, and the complex, $\mathrm{MCl}^{+}(\mathrm{M}=\mathrm{Ca}$ or $\mathrm{Mg})$. According to the data presented by Sposito et al. (1983), as the charge fraction of $\mathrm{Ca}$ (II) increases beyond 0.3 in mixed $\mathrm{NaCl} / \mathrm{CaCl}_{2}$ solutions reacting with a $\mathrm{Na}$-montmorillonite, the species of $\mathrm{Ca}$ (II) that competes effectively with $\mathrm{Na}^{+}$on the external surfaces of the quasicrystals that have formed is the complex, $\mathrm{CaCl}^{+}$, not the free cation, $\mathrm{Ca}^{2+}$. In the case of $\mathrm{Na}-\mathrm{Mg}$ exchange, the same process was shown to occur, but to a lesser extent because montmorillonite apparently exhibits a lesser affinity for $\mathrm{MgCl}^{+}$than for $\mathrm{CaCl}^{+}$(Sposito et al., 1983, Fig. 1).

The significance of the results of Sposito et al. (1983) for cation selectivity in $\mathrm{Na}-\mathrm{Ca}-\mathrm{Mg}$ exchanges on montmorillonite is the possibility that the small overall preference of $\mathrm{Ca}$ (II) over $\mathrm{Mg}$ (II) that has been observed repeatedly in chloride background media may, in fact, be produced by the greater affinity of the species $\mathrm{CaCl}^{+}$for the clay relative to the species $\mathrm{MgCl}^{+}$. It is possible that, without the presence of monovalent chloride complexes, montmorillonite would exhibit no differences in $\mathrm{Ca}$ (II) vs. $\mathrm{Mg}$ (II) selectivity in exchange reactions involving solely the free cations, $\mathrm{Na}^{+}, \mathrm{Ca}^{2+}$, and $\mathrm{Mg}^{2+}$. In this paper, the first measurements of $\mathrm{Ca}$ 
$\rightarrow \mathrm{Mg}$ exchange on montmorillonite in a perchlorate background, where monovalent complexes do not occur, will be presented. Thermodynamic methods will be applied to examine cation selectivity in $\mathrm{Na} \rightarrow \mathrm{Ca}$, $\mathrm{Na} \rightarrow \mathrm{Mg}$, and $\mathrm{Ca} \rightarrow \mathrm{Mg}$ exchange reactions on Wyoming bentonite at $298 \mathrm{~K}$ in both perchlorate and chloride background media. On the basis of this analysis, the role of the complex, $\mathrm{MCl}^{+}(\mathrm{M}=\mathrm{Ca}$ or $\mathrm{Mg})$, will be evaluated in relation to the frequent observation that montmorillonites and montmorillonitic soils adsorb $\mathrm{Ca}(\mathrm{II})$ preferentially to $\mathrm{Mg}(\mathrm{II})$.

\section{MATERIALS AND METHODS}

\section{Wyoming Bentonite}

Montmorillonite SWy-1, obtained from the Source Clays Repository of the Clay Minerals Society, was used in this study. The unit cell formula for this Crook County, Wyoming, bentonite is (Sposito et al., 1983):

$\mathrm{M}_{0.62}^{\dagger}\left(\mathrm{Si}_{7.80} \mathrm{Al}_{0.20}\right)\left[\mathrm{Al}_{3.28} \mathrm{Fe}(\mathrm{III})_{0.30} \mathrm{Fe}(\mathrm{II})_{0.04} \mathrm{Mg}_{0.38}\right] \mathrm{O}_{20}(\mathrm{OH})_{4}$, where $\mathrm{M}^{+}$refers to $1 \mathrm{~mol}$ of monovalent exchangeable cation charge. The procedures employed to purify the clay and prepare it in the sodium-saturated form in either a perchlorate or a chloride background medium have been described in detail by Sposito et al. (1981, 1983). For the exchange experiments involving only calcium and magnesium, the sodium-clay in the perchlorate medium was converted to a calcium-saturated clay by repeated washing (including a 15min shaking period) and centrifugation with $\left.2 \mathrm{M} \mathrm{Ca}_{(\mathrm{ClO}}\right)_{2}$.

\section{Exchange Experiments}

Sodium-montmorillonite samples were reacted at $25.0 \pm$ $0.3^{\circ} \mathrm{C}$ with mixed salt solutions of either $\mathrm{NaClO}_{4} / \mathrm{Ca}\left(\mathrm{ClO}_{4}\right)_{2}$, $\mathrm{NaClO}_{4} / \mathrm{Mg}\left(\mathrm{ClO}_{4}\right)_{2}, \mathrm{NaCl} / \mathrm{CaCl}_{2}$, or $\mathrm{NaCl} / \mathrm{MgCl}_{2}$, as described by Sposito et al. (1983). Calcium-montmorillonite samples were reacted at $25.0 \pm 0.3^{\circ} \mathrm{C}$ with $\mathrm{Ca}\left(\mathrm{ClO}_{4}\right)_{2} /$ $\mathrm{Mg}\left(\mathrm{ClO}_{4}\right)_{2}$ solutions. The reaction times varied between 24 and $60 \mathrm{~h}$. In the Na-exchange experiments, the anion molarity was maintained at $0.051 \pm 0.004 M$ and the $\mathrm{pH}$ value was $7.0 \pm 0.5$. In the $\mathrm{Ca}-\mathrm{Mg}$ exchange experiments, the perchlorate molarity was $0.048 \pm 0.003 M$ and the $\mathrm{pH}$ value was 7.1 \pm 0.3 . The clay stock suspension concentration was $23.2 \pm 0.2 \mathrm{~g}$ clay $/ \mathrm{kg}$ suspension. The methods by which the supernatant solutions and clay slurries were analyzed for $\mathrm{Na}$, $\mathrm{Ca}$, and $\mathrm{Mg}$ after the exchange experiments were completed have been described by Sposito et al. (1983).

\section{Data Analysis}

The surface excesses of $\mathrm{Na}, \mathrm{Ca}$, and $\mathrm{Mg}$ were calculated as described by Sposito et al. (1981):

$$
\Gamma_{i}^{(w)}=n_{i}-M_{w} m_{i}, \quad\left(i=\mathrm{Na}^{+}, \mathrm{Ca}^{2+}, \text { or } \mathrm{Mg}^{2+}\right),
$$

where $\Gamma_{i}^{(w)}$ is the surface excess, in moles per kilogram of clay; $n_{i}$ is the total number of moles of metal species $i$ in the clay slurry per kilogram of clay; $M_{w}$ is the mass of water in the clay slurry per kilogram of clay; and $m_{i}$ is the molality of metal species $i$ in the supernatant solution. The quantity $\Gamma_{i}^{(w)}$ is the number of excess moles of metal species $i$, per kilogram of clay, relative to the number of moles of the metal species present in a bulk aqueous solution of molality $m_{i}$ that contains the same mass of water as in the clay slurry.

The adsorbed metal species charge was calculated with the following equation:

$$
q_{i}=Z_{i} \Gamma_{i}^{(w)} \quad\left(i=\mathrm{Na}^{+}, \mathrm{Ca}^{2+}, \text { etc. }\right),
$$

where $Z_{i}$ is the valence of metal species $i$. The total adsorbed metal charge, $Q_{o}$, was calculated as the sum of all terms $q_{i}$ for the specific metal cation species adsorbed by the clay in a given exchange experiment.

Exchange isotherms for $\mathrm{Na}^{+}$in either the perchlorate or the chloride background ionic medium were prepared after calculating the two charge fractions:

$$
E_{\mathrm{Na}}=q_{\mathrm{Na}+} / Q_{o} \quad \tilde{E}_{\mathrm{Na}}=\left[\mathrm{Na}^{+}\right] / 0.05,
$$

where the square brackets refer to a molar concentration. The mean values of $Q_{o}$ were 1.03 and $0.9 \mathrm{~mol}_{c} \mathrm{~kg}^{-1}$, for the $\mathrm{Na}-\mathrm{Ca}$ and $\mathrm{Na}-\mathrm{Mg}$ exchanges in a $0.05 \mathrm{M}$ perchlorate background, and 0.96 and $1.04 \mathrm{~mol}_{c} \mathrm{~kg}^{-1}$ for the same two exchanges in a $0.05 \mathrm{M}$ chloride background (Sposito et al., 1983). The standard error for all four sets of measurements of $Q_{o}$ was $0.08 \mathrm{~mol}_{c} \mathrm{~kg}^{-1}$. Exchange isotherms for $\mathrm{Mg}^{2+}$ in the Ca$\mathrm{Mg}-\mathrm{ClO}_{4}$ system were prepared with charge fractions calculated similarly to those in Eq. [5]:

$$
E_{\mathrm{Mg}}=q_{\mathrm{Mg}^{2}+} / Q_{o} \quad \tilde{E}_{\mathrm{Mg}}=2\left[\mathrm{Mg}^{2+}\right] / 0.05 .
$$

Vanselow selectivity coefficients for $\mathrm{Na}^{+} \rightarrow \mathrm{Ca}^{2+}, \mathrm{CaCl}^{+}$ $\rightarrow \mathrm{Ca}^{2+}, \mathrm{Na}^{+} \rightarrow \mathrm{CaCl}^{+}, \mathrm{Na}^{+} \rightarrow \mathrm{Mg}^{2+}, \mathrm{MgCl}^{+} \rightarrow \mathrm{Mg}^{2+}$, and $\mathrm{Na}^{+} \rightarrow \mathrm{MgCl}^{+}$exchanges in the $0.05 \mathrm{M}$ chloride background were calculated from the data in Tables 4 to 7 of Sposito et al. (1983) with the following equation (Sposito, 1981, Chap. 5; Chu and Sposito, 1981):

$$
{ }^{c} K_{i j}^{T}=\left(x_{j}^{Z_{i}}(i)^{Z_{j}}\right) /\left(x_{i}^{Z_{j}}(j)^{Z_{i}}\right), \quad(i, j=1,2,3),
$$

where $x$ is a mole fraction of a metal species in the exchanger phase, () refers to an activity of a metal species in the aqueous solution phase, and $i$ or $j$ refer to metal species with valence $Z_{i}$ or $Z_{j}$. The superscript $T$ emphasizes the fact that $\mathrm{Na}-\mathrm{Ca}$ and $\mathrm{Na}-\mathrm{Mg}$ exchanges in a chloride background medium involve the ternary cation system, $\mathrm{Na}^{+}-\mathrm{M}^{2+}-\mathrm{MCl}^{+}$(Sposito et al., 1983). The activities in Eq. [7] were calculated as products of single-ion molar concentrations and single-ion activity coefficients estimated with the Davies equation (Sposito, 1981, Chap. 2). When no confusion results, ${ }^{c} K_{i j}^{T}$ will be denoted generically by the symbol $K_{V}^{T}$ (Vanselow coefficient in a ternary exchange system). This selectivity coefficient differs from that in Eq. [1] because it contains species concentrations and mole fractions instead of total concentrations and mole fractions.

\section{RESULTS AND DISCUSSION}

The primary data for $\mathrm{Ca}^{2+} \rightarrow \mathrm{Mg}^{2+}$ exchange in $0.05 \mathrm{M}$ perchlorate are given in Table 1 in terms of $c$, the equilibrium molinity (Whitfield, 1979, p. 161) in the aqueous solution phase, and $q$, the adsorbed cation charge. The mean value of $Q_{o}$ for the $\mathrm{Ca}-\mathrm{Mg}$ exchange experiments was $0.96 \pm 0.07 \mathrm{~mol}_{c} \mathrm{~kg}^{-1}$, in agreement with the mean value of $0.97 \pm 0.06 \mathrm{~mol}_{c} \mathrm{~kg}^{-1}$ reported by Sposito et al. (1983) for $\mathrm{Na}-\mathrm{Ca}$ and $\mathrm{Na}-\mathrm{Mg}$ exchanges in $0.05 \mathrm{M}$ perchlorate.

\begin{tabular}{|c|c|c|c|c|}
\hline$c_{\mathrm{Ca}}$ & $c_{\mathrm{Mg}}$ & $q_{\mathrm{Ca}}$ & $q_{\mathrm{Mg}}$ & $Q_{o}$ \\
\hline$m \mathrm{~m}$ & $\mathbf{k g}^{-1}$ & & $\mathrm{~mol}_{c} \mathbf{k g}^{-1}$ & \\
\hline $22.90 \pm 0.05$ & $<10^{-5}$ & $0.98 \pm 0.02$ & $<10^{-4}$ & 0.98 \\
\hline $21.7 \pm 0.1$ & $2.45 \pm 0.05$ & $0.88 \pm 0.09$ & $0.106 \pm 0.027$ & 0.99 \\
\hline $19.33 \pm 0.03$ & $5.04 \pm 0.04$ & $0.86 \pm 0.13$ & $0.20 \pm 0.07$ & 1.06 \\
\hline $21.0 \pm 0.1$ & $6.60 \pm 0.07$ & $0.67 \pm 0.12$ & $0.19 \pm 0.05$ & 0.86 \\
\hline $15.8 \pm 0.1$ & $8.03 \pm 0.03$ & $0.63 \pm 0.11$ & $0.32 \pm 0.05$ & 0.95 \\
\hline $13.55 \pm 0.04$ & $9.87 \pm 0.05$ & $0.52 \pm 0.07$ & $0.36 \pm 0.04$ & 0.88 \\
\hline $11.50 \pm 0.03$ & $9.15 \pm 0.07$ & $0.53 \pm 0.05$ & $0.45 \pm 0.07$ & 0.98 \\
\hline $8.80 \pm 0.05$ & $14.86 \pm 0.02$ & $0.38 \pm 0.04$ & $0.67 \pm 0.11$ & 1.05 \\
\hline $3.90 \pm 0.04$ & $19.5 \pm 0.10$ & $0.18 \pm 0.01$ & $0.72 \pm 0.04$ & 0.90 \\
\hline $2.10 \pm 0.02$ & $22.3 \pm 0.1$ & $0.06 \pm 0.02$ & $0.89 \pm 0.16$ & 0.95 \\
\hline
\end{tabular}

Exchange isotherms for $\mathrm{Na}^{+}$on $\mathrm{Ca}-$ and $\mathrm{Mg}$-montmorillonite (Wyoming bentonite) are shown in Fig. 1

Table 1-Experimental data on $\mathrm{Ca}-\mathrm{Mg}$ exchange on Wyoming bentonite in a $0.05 M$ perchlorate background. 


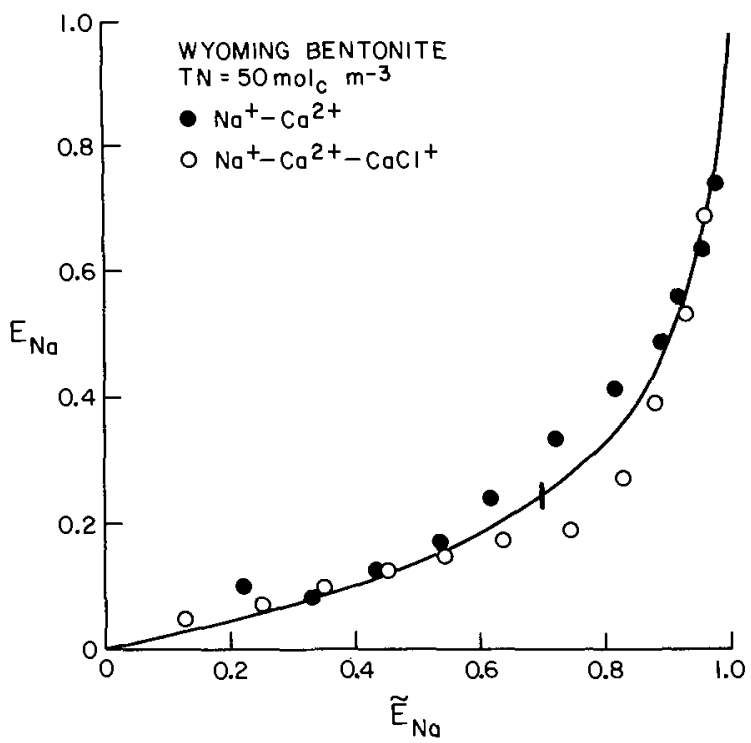

Fig. 1-Exchange isotherms for $\mathrm{Na}^{+}$in $\mathrm{Na} \rightarrow \mathrm{Ca}$ exchange on $\mathrm{Wy}-$ oming bentonite in perchlorate $(O)$ and chloride $(O)$ background media. The solid curve is the thermodynamic nonpreference isotherm for monovalent-bivalent cation exchange.

and 2 , respectively. The solid curve in each figure is the thermodynamic nonpreference isotherm for a $b i$ nary monovalent-bivalent cation exchange, calculated with the equation (Sposito, 1981, Chap. 5)

$$
E_{\mathrm{Na}}=\left[1+\frac{2}{\Gamma \mathrm{TN}}\left(\frac{1}{\tilde{E}_{\mathrm{Na}}^{2}}-\frac{1}{\tilde{E}_{\mathrm{Na}}}\right)\right]^{-1 / 2} \text {, }
$$

where $\boldsymbol{\Gamma}=\gamma_{\mathrm{Na}}^{2} / \gamma_{\mathrm{Ca}}, \gamma$ is a single-ion activity coefficient, and TN is the total cation normality (equal to the anion molarity). The thermodynamic nonpreference exchange isotherm is defined by these conditions: (i) that the standard Gibbs energy change for the exchange reaction is zero $\left(\Delta G_{\mathrm{ex}}^{\circ}=0\right)$, and (ii) that the exchanger phase activity coefficients have unit value (ideal mixture). Thus, in chemical thermodynamics, cation exchange is said to exhibit no selectivity if the exchange equilibrium constant is equal to 1.0 and the exchanger phase has the properties of an ideal solid solution. The vertical lines through the nonpreference isotherms in Fig. 1 and 2 indicate the standard errors in the measured values of $E_{\mathrm{Na}}$, which were \pm 0.02 for $\mathrm{Na}-\mathrm{Ca}$ exchanges and \pm 0.03 for $\mathrm{Na}-\mathrm{Mg}$ exchanges.

The data in Fig. 1 and 2 indicate that, in the perchlorate background, Wyoming bentonite shows approximately no preference for $\mathrm{Na}^{+}$in either $\mathrm{Na}-\mathrm{Ca}$ or $\mathrm{Na}-\mathrm{Mg}$ exchange, according to the thermodynamic criterion of nonpreference described above. On a finer scale of examination, the data for the perchlorate medium in Fig. 1 and 2 suggest that $\mathrm{Na}^{+}$may be preferred slightly over $\mathrm{Ca}^{2+}$, and $\mathrm{Mg}^{2+}$ may be preferred slightly over $\mathrm{Na}^{+}$, when $0.1<E_{\mathrm{Na}}<0.4$.

A $\mathrm{Na} / \mathrm{Ca}-$ or $\mathrm{Na} / \mathrm{Mg}$-montmorillonite suspension with $<30 \%$ of the total adsorbed metal charge accounted for by $\mathrm{Na}^{+}$comprises fully developed quasicrystals, with bivalent exchangeable cations principally in the interlayer regions and $\mathrm{Na}^{+}$relegated to the external surfaces (Shainberg and Otoh, 1968; BarOn et al., 1970). Exchange reactions involving $\mathrm{Na}^{+}$ for $E_{\mathrm{Na}}<0.4$ can, therefore, be expected to occur

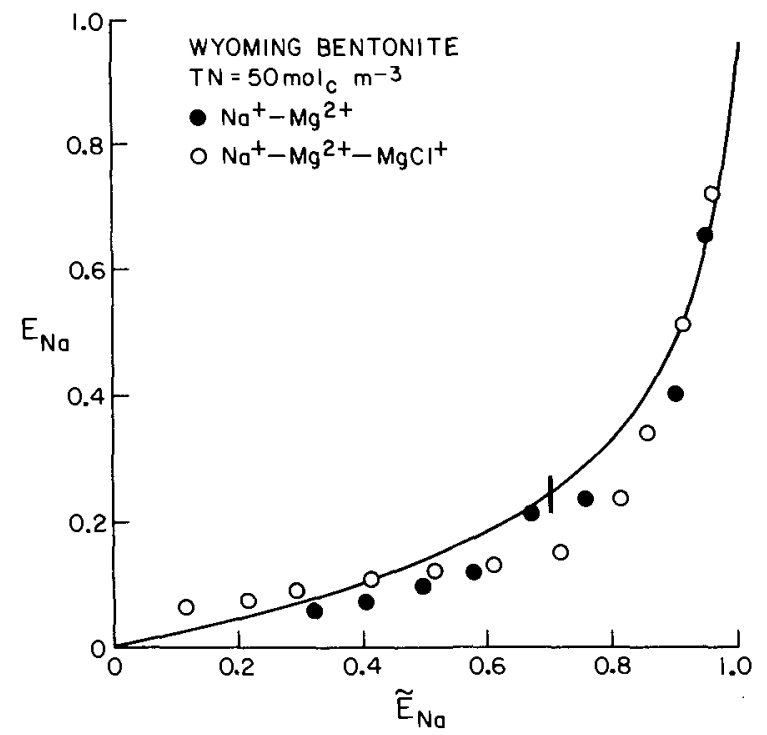

Fig. 2-Exchange isotherms for $\mathrm{Na}^{+}$in $\mathrm{Na} \rightarrow \mathrm{Mg}$ exchange on Wyoming bentonite in perchlorate $(0)$ and chloride $(O)$ background media. The solid curve is the nonpreference isotherm for monovalent-bivalent cation exchange.

principally on external surfaces. On the hypothesis of Sposito et al. (1983), the monovalent complexes, $\mathrm{CaCl}^{+}$ and $\mathrm{MgCl}^{+}$, can compete with $\mathrm{Na}^{+}$on the external surfaces more effectively than $\mathrm{Ca}^{2+}$ or $\mathrm{Mg}^{2+}$. This competition, however, is less intense for $\mathrm{MgCl}^{+}$than for $\mathrm{CaCl}^{+}$because the former complex is less stable thermodynamically and has a lesser affinity for the clay than the latter complex (Sposito et al., 1983, Table 1 and Fig. 1). Perhaps these two characteristics are the cause of the more apparent downward shift of $\mathrm{Na}^{+}$ selectivity in $\mathrm{Na}-\mathrm{Ca}$ exchange than in $\mathrm{Na}-\mathrm{Mg}$ exchange, noted in Fig. 1 and 2, when the background anion is changed from perchlorate to chloride.

Table 2-Vanselow selectivity coefficients and exchanger-phase composition date (mole fractions) for $\mathrm{Na}^{+}-\mathrm{M}^{2+}-\mathrm{MCl}^{+}$ exchange ( $\mathrm{M}=\mathrm{Ca}$ or $\mathrm{Mg}$ ) on Wyoming bentonite in a $0.05 M$ chloride background.

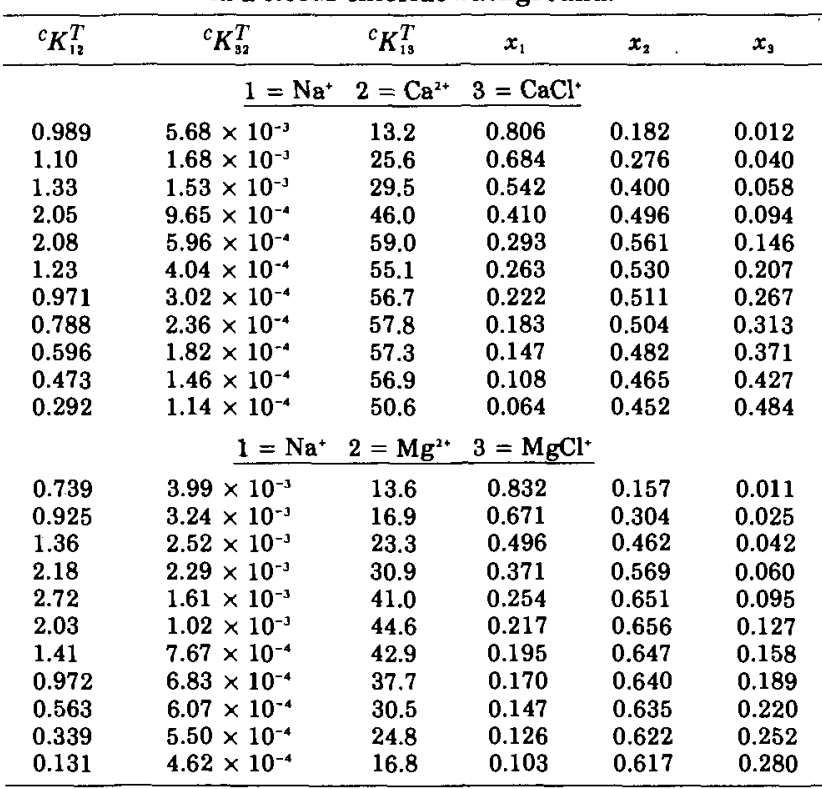




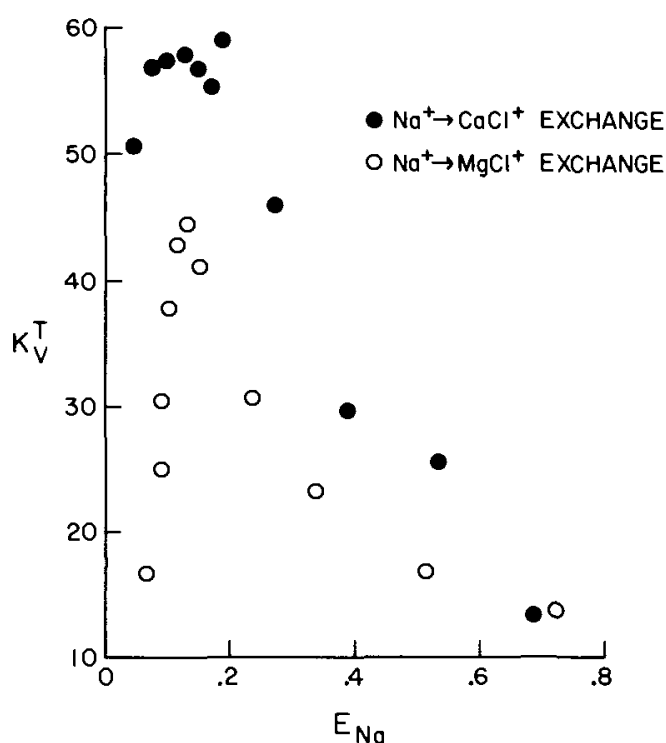

Fig. 3-The Vanselow selectivity coefficient for $\mathrm{Na}^{+} \rightarrow \mathrm{MCl}^{+}$exchange ( $\mathrm{M}=\mathrm{Ca}$ or $\mathrm{Mg}$ ) on Wyoming bentonite as a function of the charge fraction of $\mathrm{Na}^{+}$on the clay.

The differences between Fig. 1 and 2 can be elucidated further through an examination of Table 2. This table lists values for three ternary Vanselow selectivity coefficients along with the mole fractions of $\mathrm{Na}^{+}, \mathrm{M}^{2+}$, and $\mathrm{MCl}^{+}(\mathrm{M}=\mathrm{Ca}$ or $\mathrm{Mg})$ on montmorillonite suspended in the chloride background medium. The selectivity coefficients in the first three columns of the table were calculated with Eq. [7] and refer to $\mathrm{Na}^{+} \rightarrow$ $\mathrm{M}^{2+}, \mathrm{MCl}^{+} \rightarrow \mathrm{M}^{2+}$, and $\mathrm{Na}^{+} \rightarrow \mathrm{MCl}^{+}$exchange, respectively, where $\mathrm{M}=\mathrm{Ca}$ or $\mathrm{Mg}$. The exchanger composition data at a mole fraction of $\mathrm{Na}^{+}$of 0.1 or less indicate that approximately equal numbers of the species, $\mathrm{Ca}^{2+}$ and $\mathrm{CaCl}^{+}$, are adsorbed. However, only about one-half as many $\mathrm{MgCl}^{+}$are adsorbed as there are $\mathrm{Mg}^{2+}$ on the clay surface. The calcium distribution, which is equivalent to two-thirds of $Q_{0}$ satisfied by $\mathrm{Ca}^{2+}$ and one-third by $\mathrm{CaCl}^{+}$, is consistent with the concept developed by Sposito et al. (1983), in which a Ca-montmorillonite suspended in a chloride ionic medium consists of quasicrystals having $\mathrm{Ca}^{2+}$ principally in the interlayer regions and $\mathrm{CaCl}^{+}$principally on the external surfaces. However, in the case of $\mathrm{Mg}$ montmorillonite, only about one-half of the charge on external surfaces evidently is neutralized by adsorbed $\mathrm{MgCl}^{+}$. This smaller adsorption of $\mathrm{MgCl}^{+}$reflects a smaller effect of the complex on $\mathrm{Na}^{+}$selectivity, in agreement with the negligible difference between the isotherms in Fig. 2.

The third column of Table 2 lists values of $K_{V}^{T}$ for the exchanges: $\mathrm{Na}^{+} \rightarrow \mathrm{CaCl}^{+}$and $\mathrm{Na}^{+} \rightarrow \mathrm{MgCl}^{+}$. These selectivity coefficients are plotted against $E_{\mathrm{Na}}$ in Fig. 3. Since $K_{V}^{T} \gg 1.0$ for both exchanges, the clay surface is selective for $\mathrm{CaCl}^{+}$and $\mathrm{MgCl}^{+}$over $\mathrm{Na}^{+}$. As $E_{\mathrm{Na}}$ decreases below $0.4, K_{V}^{T}$ increases sharply and reaches a maximum value at $E_{\mathrm{Na}} \approx 0.15$, thereafter appearing to drop precipitously. The most rapid increase of $K_{V}^{T}$ with decreasing $E_{\mathrm{Na}}$ occurs after quasicrystal formation, when the remaining exchangeable $\mathrm{Na}^{+}$reside on external surfaces $\left(E_{\mathrm{Na}}<0.4\right)$. The reason for this behavior cannot be determined on the

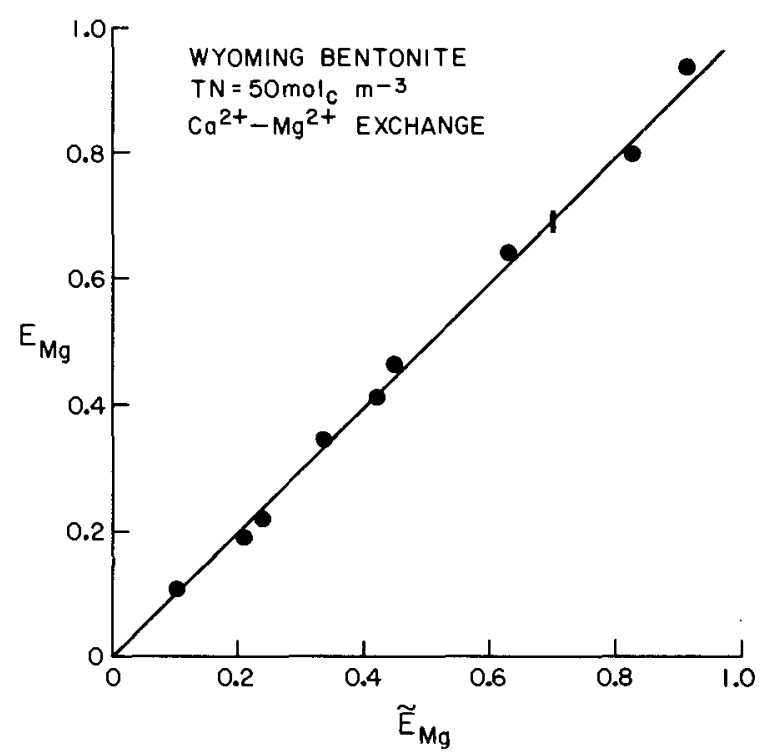

Fig. 4-Exchange isotherm for $\mathrm{Mg}^{2+}$ in $\mathrm{Ca} \rightarrow \mathrm{Mg}$ exchange on Wyoming bentonite in $0.05 M$ perchlorate. The solid line is the thermodynamic nonpreference isotherm.

basis of thermodynamic data alone. One possibility is related to the gradual breakdown of quasicrystals that has been observed to begin when $E_{\mathrm{Na}} \geq 0.15$ on Wyoming bentonite (Shainberg and Otoh, 1968; Banin, 1968; Bar-On et al., 1970; Dufey and Banin, 1979). When $E_{\mathrm{Na}}$ is very near zero, the quasicrystals remain intact and $\mathrm{MCl}^{+}$is, evidently, increasingly preferred as $E_{\mathrm{Na}}$ grows larger. When $E_{\mathrm{Na}}>0.15$ and the quasicrystals start to disintegrate, the high selectivity for $\mathrm{MCl}^{+}$drops off because $\mathrm{Na}^{+}$now is exchanging on both external and internal surfaces. The combination of these two trends could produce the behavior in Fig. 3.

Figure 4 shows an exchange isotherm, for $\mathrm{Mg}^{2+}$ in $\mathrm{Ca}^{2+} \rightarrow \mathrm{Mg}^{2+}$ exchange on Wyoming bentonite, which was constructed with Eq. [6] from the data in Table 1. The thermodynamic nonpreference isotherm in this case is the straight line in the figure that makes a 45degree angle with both coordinate axes (Sposito, 1981, Chap. 5). The vertical bar indicates the standard error in the measurements of $E_{\mathrm{Mg}}$, which was \pm 0.01 . It is apparent that, within the experimental precision, there is no preference for $\mathrm{Mg}^{2+}$ over $\mathrm{Ca}^{2+}$ on the clay mineral. A direct computation of the binary Vanselow selectivity coefficient,

$$
K_{V}^{B}=\frac{x_{\mathrm{Mg}^{2+}}\left(\mathrm{Ca}^{2+}\right)}{x_{\mathrm{Ca}^{2+}}\left(\mathrm{Mg}^{2+}\right)},
$$

for each set of exchange data in Table 1 resulted in $K_{V}^{B}=1.0 \pm 0.2$, thereby confirming the implication of Fig. 4. Within its experimental precision, this result is not in contradiction with the slight preference of $\mathrm{Na}^{+}$over $\mathrm{Ca}^{2+}$ in a perchlorate background, indicated in Fig. 1, or the slight preference of $\mathrm{Mg}^{2+}$ over $\mathrm{Na}^{+}$ in a perchlorate background, indicated in Fig. 2. Since $K_{V}^{B}$ in this case is equal to the ratio of the equilibrium constant for $\mathrm{Na}^{+} \rightarrow \mathrm{Mg}^{2+}$ exchange to that for $\mathrm{Na}^{+}$ $\rightarrow \mathrm{Ca}^{2+}$ exchange, the former constant could be as much as $20 \%$ larger than the latter constant and still 
be consistent with the reported standard deviation of \pm 0.2 for $K_{V}^{B}$.

The isotherm in Fig. 4 differs from the results of the many studies that have been reported previously for $\mathrm{Ca}(\mathrm{II})-\mathrm{Mg}(\mathrm{II})$ exchange in chloride background media (Clark, 1966; Hunsaker and Pratt, 1971; Levy et al., 1972; Levy and Shainberg, 1972; Gheyi and van Bladel, 1975; van Bladel and Gheyi, 1980), which imply a slight preference for $\mathrm{Ca}(\mathrm{II})$ over $\mathrm{Mg}(\mathrm{II})$. The mean values of the overall Vanselow selectivity coefficient for $\mathrm{Mg}(\mathrm{II}) \rightarrow \mathrm{Ca}$ (II) exchange (the inverse of $K_{T V}$ in Eq. [1]) that can be calculated from the data reported by Levy and Shainberg (1972) and by van Bladel and Gheyi (1980) are $1.47 \pm 0.19$ and $1.26 \pm 0.20$, respectively. The differences between these two results and the mean $K_{V}^{B}$ determined in this study are concluded to be the result of the greater affinity of the clay for $\mathrm{CaCl}^{+}$vs. $\mathrm{MgCl}^{+}$in a chloride background medium.

\section{CONCLUSIONS}

In a $0.05 \mathrm{M}$ perchlorate background at $25^{\circ} \mathrm{C}$, the exchange isotherm for $\mathrm{Na}^{+}$competing either with $\mathrm{Ca}^{2+}$ or $\mathrm{Mg}^{2+}$ on Wyoming bentonite is very nearly congruent with the thermodynamic nonpreference isotherm. When the charge fraction of $\mathrm{Na}^{+}$on the clay lies between 0.1 and 0.4 , there is, at most, a slight preference for $\mathrm{Na}^{+}$over $\mathrm{Ca}^{2+}$ and for $\mathrm{Mg}^{2+}$ over $\mathrm{Na}^{+}$. The small enhancement in $\mathrm{Mg}^{2+}$ selectivity may be a result of the fact that about one-third of the permanent charge on the clay originates in the tetrahedral sheet, thus endowing the clay with some "vermiculite-like" character and a slight preference for $\mathrm{Mg}^{2+}$.

In a $0.05 \mathrm{M}$ chloride background, the exchange isotherm for $\mathrm{Na}^{+}$competing with species of $\mathrm{Mg}$ (II) does not appear to be detectably different from the corresponding isotherm in a perchlorate background. The exchange isotherm for $\mathrm{Na}^{+}$competing with species of $\mathrm{Ca}$ (II) in a $0.05 \mathrm{M}$ chloride background does shift downward, however, to indicate a slight increase in preference for calcium species over $\mathrm{Na}^{+}$when $E_{\mathrm{Na}}$ drops below 0.4 . This shift is caused by the formation of $\mathrm{CaCl}^{+}$complexes which compete strongly with $\mathrm{Na}^{+}$ on the external surfaces of quasicrystals.

In a $0.05 \mathrm{M}$ perchlorate background at $25^{\circ} \mathrm{C}$, the exchange isotherm for $\mathrm{Mg}^{2+}$ competing with $\mathrm{Ca}^{2+}$ on Wyoming bentonite is indistinguishable, within experimental precision, from a thermodynamic nonpreference isotherm. Reports of a small preference for $\mathrm{Ca}$ (II) over $\mathrm{Mg}$ (II) on Wyoming bentonite in chloride background media reflect the greater affinity of the clay for $\mathrm{CaCl}^{+}$vs. $\mathrm{MgCl}^{+}$.

\section{ACKNOWLEDGMENTS}

The research reported in this paper was supported in part by a grant from the Kearney Foundation of Soil Science and in part by a grant-in-aid to $\mathrm{L}$. Charlet from the Graduate Division of the University of California, Riverside. Gratitude also is expressed for a research fellowship to Dr. C. Jouany from the French Ministry of Foreign Affairs. Dr. Philip Fletcher kindly read this paper in early draft form and made several helpful comments towards its improvement.

\section{REFERENCES}

1. Banin, A. 1968. Ion exchange isotherms of montmorillonite and structural factors affecting them. Israel J. Chem. 6:27-36.

2. Bar-On, P., I. Shainberg, and I. Michaeli. 1970. Electrophoretic mobility of montmorillonite particles saturated with $\mathrm{Na} / \mathrm{Ca}$ ions. J. Colloid Interface Sci. 33:471-472.

3. Bresler, E., B.L. McNeal, and D.L. Carter. 1982. Saline and sodic soils. Springer-Verlag, Berlin.

4. Chu, S.-Y., and G. Sposito. 1981. The thermodynamics of ternary cation exchange systems and the subregular model. Soil Sci. Soc. Am. J. 45:1084-1089.

5. Clark, J.S. 1966. The distribution constant for exchange of Ca and $\mathrm{Mg}$ in Wyoming bentonite. Can. J. Soil Sci. 46:271-280.

6. Dolcater, D.L., E.G. Lotse, J.K. Syers, and M.L. Jackson. 1968. Cation exchange selectivity of some clay-sized minerals and soil materials. Soil Sci. Soc. Am. J. 32:795-798.

7. Dufey, J.E., and A. Banin. 1979. Particle shape and size of two sodium calcium montmorillonite clays. Soil Sci. Soc. Am. J. 43:782-785.

8. Gheyi, H.R., and R. van Bladel. 1975. Calcium-sodium and calcium-magnesium exchange equilibria on some calcareous soils and a montmorillonite clay. Agrochimica 19:468-477.

9. Hunsaker, V.E., and P.F. Pratt. 1971. Calcium magnesium exchange equilibria in soils. Soil Sci. Soc. Am. J. 35:151-152.

10. Jensen, H.E. 1972. Cation adsorption isotherms derived from mass-action theory. Royal Vet. Agric. Univ. (Copenhagen) Yearbook 1972:88-103.

11. Jensen, H.E., and K.L. Babcock. 1973. Cation-exchange equilibria on a Yolo loam. Hilgardia 41:475-488.

12. Levy, R., and D. Hillel. 1968. Thermodynamic equilibrium constants of sodium-calcium exchange in some Israel soils. Soil Sci. 106:393-398.

13. Levy, R., and I. Shainberg. 1972. Calcium-magnesium exchange in montmorillonite and vermiculite. Clays Clay Miner. 20:3746.

14. Levy, R., I. Shainberg, J. Shalhevet, and N. Alperovitch. 1972. Selectivity coefficients of $\mathrm{Ca}-\mathrm{Mg}$ exchange for three montmorillonite soils. Geoderma 8:133-138.

15. Maes, A., and A. Cremers. 1977. Charge density effects in ion exchange. Part 1. Heterovalent exchange equilibria. J.C.S. Faraday I 73:1807-1814.

16. Rahman, W.A., and D.L. Rowell. 1979. The influence of magnesium in saline and sodic soils: a specific effect or a problem of cation exchange? J. Soil Sci. 30:535-546.

17. Rowell, D.L., and I. Shainberg. 1979. The influence of magnesium and of easily weathered minerals on hydraulic conductivity changes in a sodic soil. J. Soil Sci. 30:719-726.

18. Schwertmann, U. 1962. Die selektive Kationensorption der Tonfraktion einiger Boden aus Sedimenten. Z. Pflanzenernahr. Dung. Bodenkunde 97:9-25.

19. Shainberg, I., and H. Otoh. 1968. Size and shape of montmorillonite particles saturated with $\mathrm{Na} / \mathrm{Ca}$ ions (inferred from viscosity and optical measurements). Israel J. Chem. 6:251-259.

20. Shainberg, I., J.D. Oster, and J.D. Wood 1980. Sodium/calcium exchange in montmorillonite and illite suspensions. Soil Sci. Soc. Am. J. 44:960-064.

21. Sposito, G. 1981. The thermodynamics of soil solutions. Clarendon Press, Oxford.

22. Sposito, G., K.M. Holtzclaw, L. Charlet, C. Jouany, and A.L. Page. 1983. Sodium-calcium and sodium-magnesium exchange on Wyoming bentonite in perchlorate and chloride background ionic media. Soil Sci. Soc. Am. J. 47:51-56.

23. Sposito, G., K.M. Holtzclaw, C.T. Johnston, and C.S. LeVesque. 1981. Thermodynamics of sodium-copper exchange on Wyoming bentonite at $298 \mathrm{~K}$. Soil Sci. Soc. Am. J. 45:10791084.

24. Van Bladel, R., G. Gavira, and H. Laudelout. 1973. A comparison of the thermodynamic, double layer theory and empirical studies of the $\mathrm{Na}$-Ca exchange equilibria in clay water systems. Proc. Int. Clay Conf. 1972:385-398.

25. Van Bladel, R., and H.R. Gheyi. 1980. Thermodynamic study of calcium-sodium and calcium-magnesium exchange in calcareous soils. Soil Sci. Soc. Am. J. 44:938-942.

26. Whitfield, M. 1979. Activity coefficients in natural waters. p. 153-299. In R.M. Pytkowicz (ed.) Activity coefficients in electrolyte solutions. CRC Press, Boca Raton, Fla. 